\title{
Drug-induced panniculitis due to deworming in a dog - case report
}

\section{Paniculite farmacodérmica decorrente de vermifugação em um cão - relato de caso}

\author{
Cayo Yuji NITTA ${ }^{1,2}$; Solange Maria GENNARI ${ }^{3}$; Juliana Isabel Giuli da Silva FERREIRA³ \\ Leandro Haroutune Hassesian GALATI ${ }^{4}$; Carlos Eduardo LARSSON ${ }^{4}$
}

\author{
${ }^{1}$ Governo do Estado de São Paulo, Secretaria de Estado da Saúde, Programa de Aprimoramento, São Paulo - SP, Brazil \\ ${ }^{2}$ Universidade de São Paulo, Faculdade de Medicina Veterinária e Zootecnia, Hospital Veterinário, São Paulo - SP, Brazil \\ ${ }^{3}$ Universidade de São Paulo, Faculdade de Medicina Veterinária e Zootecnia, Departamento de Medicina Veterinária Preventiva e Saúde \\ Animal, São Paulo - SP, Brazil \\ ${ }^{4}$ Universidade de São Paulo, Faculdade de Medicina Veterinária e Zootecnia, Departamento de Clínica Médica, São Paulo - SP, Brazil
}

\begin{abstract}
Outpatient clinics, clinics, and veterinary hospitals in the state of São Paulo and other Brazilian states commonly prescribe broad-spectrum vermicidal agents. The prescriptions are not based on coproparasitological examination results and drugs, including those used for the elimination of enteric parasites, are not innocuous and can potentially cause health hazards. Therefore, we report a clinical case of drug-induced panniculitis caused by deworming and show the actual occurrence of endoparasites in canine and feline outpatients at HOVET-USP.
\end{abstract}

Keywords: Panniculitis. Cutaneous adverse drug reaction. Anthelmintic. Coproparasitological exam.

\section{Resumo}

É prática corrente em ambulatórios, consultórios, clínicas e hospitais veterinários paulistas, por não dizer brasileiros, a prescrição de ativos com ação vermicida, no senso lato, sem o embasamento do, hoje até prosaico, exame coproparasitológico. É sabido há muito que todo e qualquer fármaco não é inócuo e pode potencialmente acarretar agravos à saúde, e dentre estes incluem-se os ativos destinados à erradicação de parasitos entéricos. Decidiu-se assim por se relatar um caso clínico de paniculite farmacodérmica decorrente de vermifugação, bem como situar a real ocorrência de endoparasitas em pacientes, caninos e felinos, trazidos para atendimento ambulatorial no HOVET-USP. Palavras-chave: Paniculite. Farmacodermia. Vermífugo. Coproparasitológico.

\section{Correspondence to:}

Cayo Yuji Nitta

Universidade de São Paulo, Faculdade de Medicina Veterinária e Zootecnia, Hospital Veterinário

Av. Prof. Dr. Orlando Marques de Paiva, 87

CEP 05508-900, São Paulo, SP, Brazil

e-mail: c.nitta@uol.com.br

Received: $18 / 06 / 2017$

Approved: 25/07/2017

Outpatient clinics, clinics, and veterinary hospitals in the state of São Paulo and other Brazilian states commonly prescribe broad-spectrum vermicidal agents. The practice is correct if the patient has worms or protozoa. Over time, even in veterinary school hospitals where clinical behavior should be evidence-based, the use of anti-endoparasitic drugs without performing a coproparasitological examination has become standard practice.

A presumed diagnosis of endoparasites and a prescription for an anthelminthic and/or protozoocidal agent should be supported by racial definition and age, anamnesis (origin of the patient, location and breed, symptoms presented, type of feeding, contact with other animals, travel, presence of ectoparasites, and previous therapy), and physical and tegumentary examinations.

This apparently well-indicated and well-adopted conduct is based on the possibility of endoparasites always being present. The abundance of drugs to combat these parasites, administered alone or in combination, has contributed to their broad use.

No drug is innocuous. Some may potentially lead to minor health problems that are temporary and resolve with discontinuation of treatment. Others may cause serious or fatal clinical conditions (SAMPAIO; RIVITTI, 2001; FERREIRA et al., 2016). These drugs include formulations for the eradication of enteric parasites (LARSSON, 1996).

The relevance of prescribing such formulations to animal patients without evidence of gastrointestinal parasitism has been the subject of discussion at clinical 
meetings. We report a clinical case of drug-induced panniculitis and dermatosis caused by deworming and assess the occurrence of endoparasites in canine and feline patients brought to the Veterinary Teaching Hospital of the University of São Paulo (HOVET-USP) that resulted from coproparasitological examinations at the Parasitology Laboratory Service of the HOVET-USP.

A 7-month-old female Lhasa Apso dog weighing $3.8 \mathrm{~kg}$ was brought to the Dermatology Unit of the Department of Clinical Medicine and the Veterinary Hospital of FMVZ-USP. Since the age of 2 months, the dog had lived with her owner and six mixed-breed cats between 1 and 3 years of age and of different weights.

Her clinical presentation was devoid of general symptoms. However, she showed the presence of a nonpruritic lesion that had presented approximately 10 days previously as a nodular-gummy lumbar lesion (Figure 1), evolving into an eroded-ulcerated presentation covered by purulent-looking material. A similar lesion was located over a bilateral periocular erythematous area extending through the nasal plane (Figure 2). There was also discreet superficial cervical lymphadenomegaly.

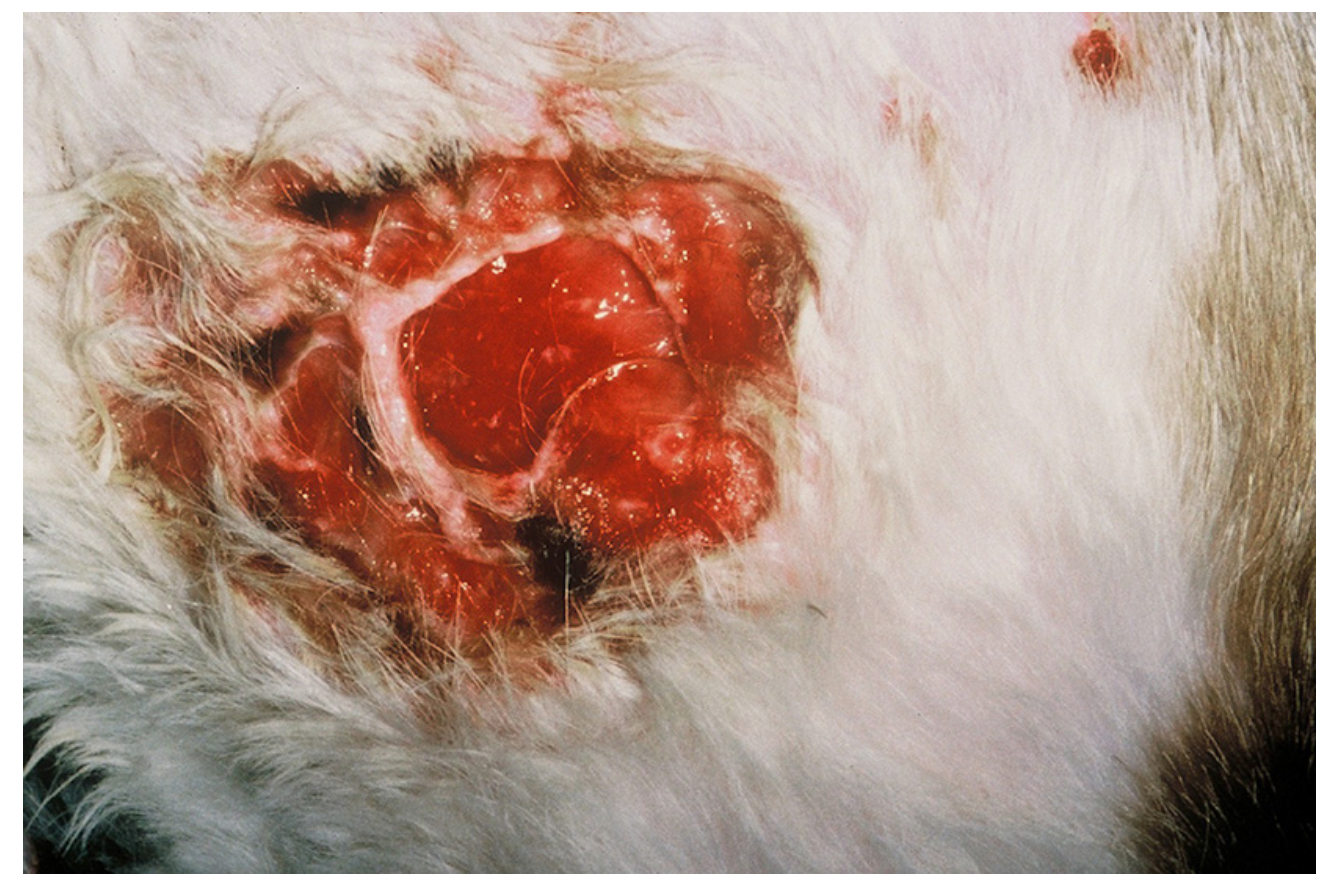

Figure 1 - Drug-induced panniculitis. A nodular gummy lesion reaching the panicle in the left thoracolumbar region - HOVET/USP - São Paulo - 2017

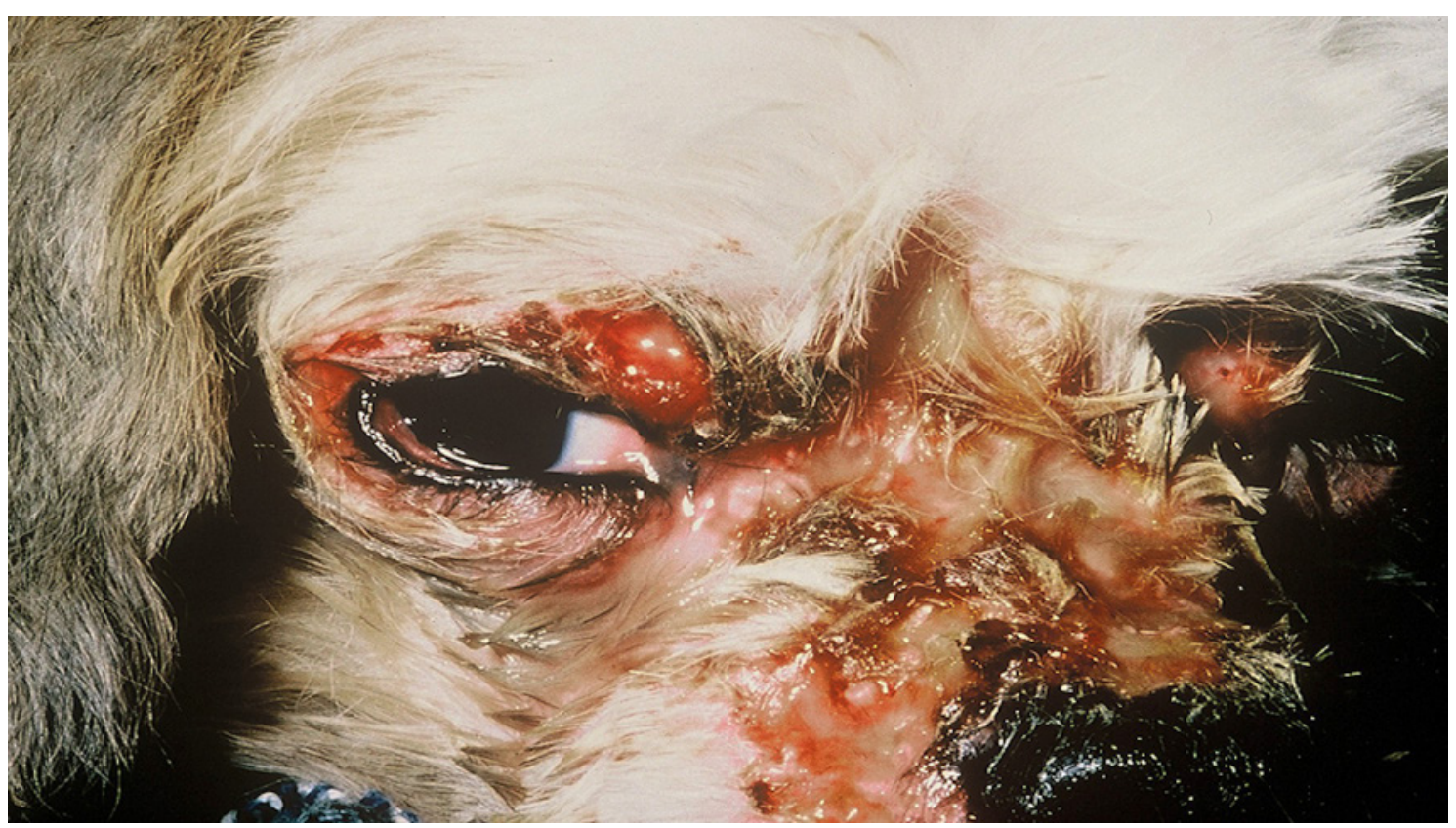

Figure 2 - Drug-induced panniculitis. Bilateral eyelid edema and phagedenic ulcer covered by purulent exudate in the periocular region - HOVET/USP - São Paulo - 2017 
Hygienic-dietary management was adequate, including two successive applications of imported heptavalent immunogen to the hemithorax contralateral to that of the lumbar lesion. Before clinical presentation, and without previous coproparasitological examination, the patient had been dewormed with a combination of febantel and pyrantel. As the clinical symptoms presented, the owner, on her own initiative, had administered oral piroxicam for 7 days and Dakin's liquid and mupirocin-based ointment topically.

Blood tests, bacterial and fungal examinations and cultures, and biopsy and histopathology of lesion material revealed slight normocytic and normochromic anemia, moderate leukocytosis with left shift, and no pathogens on direct examination or in the cultures. A pathological examination of the material from the solid lumbar lesion at the dermal and hypodermic levels revealed an interstitial edema with rare mononuclear infiltrates and neutrophilic exudate dissociating lipocytes, respectively.

It was possible to histologically characterize dermoepidermal continuity solution surmounted by a thick crust on the facial lesions. Leukocyte exudate, abscesses surrounded by mononuclear cells and macrophages, broad interlobular septa, and the presence of fibroblasts and collagen fibers were observed in the hypodermis. Fungal assessment was negative, even with specific staining. The lesion was concluded to be lobular suppurative panniculitis, abscessed and ulcerated, with an assumed idiopathic nature.

Oral prednisolone therapy was initiated at a dose of 1 $\mathrm{mg} / \mathrm{kg} /$ day, and the patient was followed up after 15 and 20 days. There was progressive and evident remission of the condition (Figures 3 and 4), and the patient was clinically discharged.

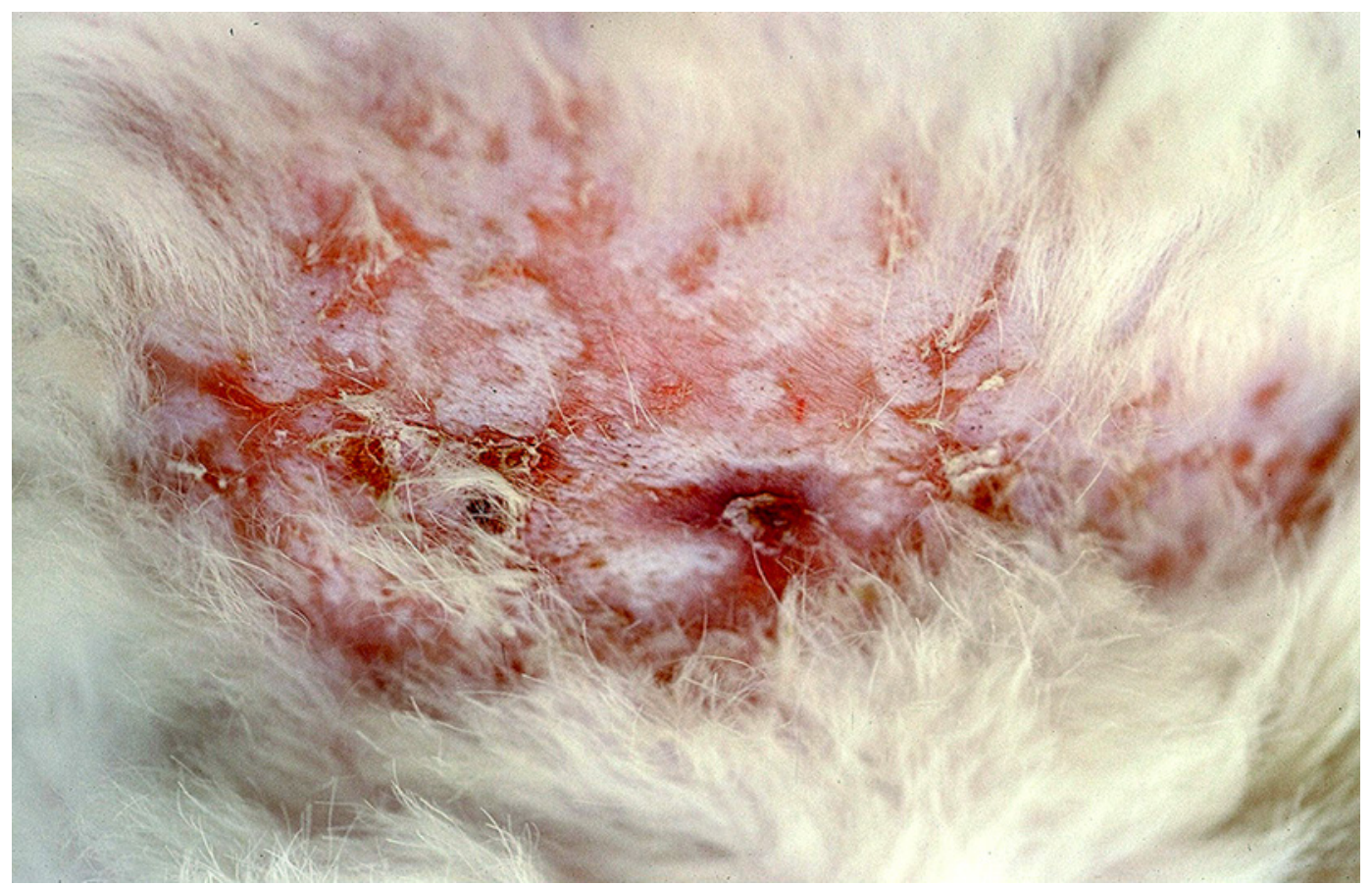

Figure 3 - Drug-induced panniculitis. A thoraco-lumbar lesion (Figure 1), still alopecic and now crusty, in the healing phase with onset of fur regrowth. Twenty days later after treatment with prednisolone - HOVET/USP - São Paulo - 2017

After approximately 7 months, the owner reported via telephone that the presentation had recurred. When asked about possible interpositions of immunogens or any other drug use, she said she had again dewormed the patient using the febantel-pyrantel combination without a coproparasitological examination. The new lesions, upon dermatological examination, were bilateral papule-nodular formations located in the lumbar region. The diagnosis of a new panniculitis was established, and was now confirmed to be of drug-induced etiology and triggered by provocative exposure by the owner.

Some reports of drug-induced presentations triggered by endectocides and dewormers in humans and animals have been published in the last 15 years, generating clinical pictures of variable severity, such as morphea simile, vasculitis, panniculitis, pemphigus foliaceus, and major polymorphous erythema (Stevens-Johnson syndrome) (CRIADO et al., 2004; NUTTALL; MALHAM, 2004; CRIADO; CRIADO, 2014). 


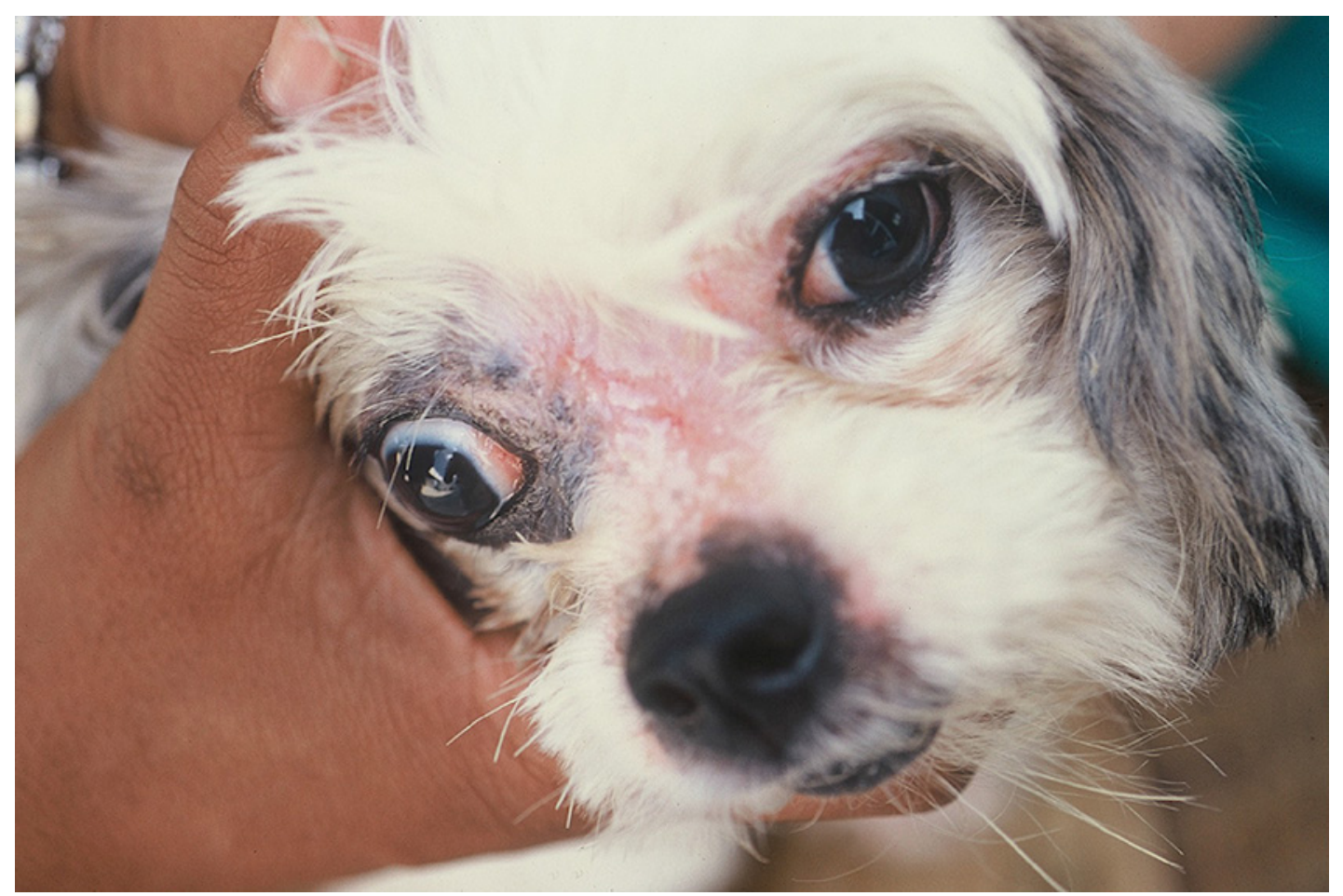

Figure 4 - Drug-induced panniculitis. Vestigial lesion (Figure 2) during the fur regrowth phase. Twenty days later after treatment with prednisolone - HOVET/USP - São Paulo - 2017

The supposed harmlessness and safety of anthelmintics according to veterinary professionals has led to widespread use (LARSSON, 1996). This case of favorable onset and relapse triggered by the owner's decision to de-worm the patient, devoid of any symptomatic enteric manifestation or evidence of helminthiasis, describes the usual conduct of clinicians and unsuspecting pet owners.

Nowadays, given the high number of companion animals kept indoors in large urban areas, where the possibility of endoparasitic infections, especially in adult animals, is smaller, dewormers should only be prescribed after the diagnose of the parasitic agent. Recent works concerning dogs and cats treated at the same veterinary hospital have shown that there is an increase in the occurrence of protozoan infections in relation to helminth infections, and these protozoa require the use of specific drugs and/or differentiated doses and time of treatment (FERREIRA et al., 2016; GENNARI et al., 2016).

Even young animals, which should always be placed in a deworming scheme due to the acquisition of nematodes through transplacental and/or milk transmission, should be accompanied by coproparasitological examinations to evaluate the interval between dosages and the choice of the active principle (FERREIRA et al., 2016; GENNARI et al., 2016).

As evidence of this assertion, the results of coproparasitological examinations conducted in the
Laboratory of Parasitic Diseases of the HOVET-USP over 23 years were collected. Between 1991 and 2014, there were 7397 coproparasitological examinations from fecal samples of 6078 dogs and 1319 cats of either sex and of different age groups from different regions of the city of São Paulo. Of those samples, 2076 (28\%) were positive. By species, $1589(26.1 \%)$ and $487(36.9 \%)$ canine and feline samples respectively were positive.

These percentages reflect a low number of positive test results. They may only represent the lowest probability of enteroparasite infestations of animals raised in developed cities, but can generate unnecessary use of antihelminthic drugs in non-parasitized animals.

Although scarce, both national and international medical literature assembled a few reports of toxidermal reactions related to anthelminthic drug use, including panniculitis. All cases were triggered by albendazole, levamisole, fenbendazole, mebendazole, thiabendazole, metronidazole, praziquantel, ivermectin, and/or emodepside (MASON, 1990; SCOTT; MILLER JUNIOR, 1999; SOUSA et al., 2005).

In the case described here, the lesion was initially characterized as ulcero-abscessed suppurative lobular panniculitis, which is among the most common types of hypodermatitis of the species. Initially, it was also considered idiopathic, as no underlying comorbidity was detected (NUTTALL; MALHAM, 2004). 
In this case, one could initially suggest vaccinal panniculitis, such as vasculopathic syndrome of the rabies immunization, as an underlying cause, as the patient had undergone subcutaneous application of heptavalent vaccine, but this vaccine does not include the rabies vaccination. Moreover, the point of application had been a contralateral thoracic site, and no other active drug had been used.

\section{References}

CRIADO, P. R.; CRIADO, R. F. J.; VASCONCELLOS, C.; RAMOS, R. O.; GONÇALVES, A. C. Reações cutâneas graves adversas a drogas: aspectos relevantes ao diagnóstico e ao tratamento: parte I: anafilaxia e reações anafilactóides, eritrodermias e o espectro clínico da síndrome de Stevens-Johnson e necrólise epidérmica tóxica (doença de Lyell). Anais Brasileiros de Dermatologia, v. 79, n. 4, p. 471-488, 2004. doi: 10.1590/S0365-05962004000400009.

CRIADO, P. R.; CRIADO, R. F. J. Reações adversas às drogas: o aspecto dermatológico na prática clínica. Barueri: Manole, 2014.

FERREIRA, J. I. G. S.; PENA, H. F. J.; AZEVEDO, S. S.; LABRUNA, M. B.; GENNARI, S. M. Occurrences of gastrointestinal parasites in fecal samples from domestic dogs in São Paulo, SP, Brazil. Revista Brasileira de Parasitologia Veterinária, v. 25, n. 4, p. 435-440, 2016. doi: 10.1590/S1984-29612016081.

GENNARI, S. M.; FERREIRA, J. I. G. S.; PENA, H. F. J.; LABRUNA, M. B.; AZEVEDO, S. S. Frequency of gastrointestinal parasites in cats seen at the University of São Paulo Veterinary Hospital, Brazil. Revista Brasileira de Parasitologia Veterinária, v. 25, n. 4, p. 423-428, 2016. doi: 10.1590/S1984-29612016082.

LARSSON, C. E. Dermatopatias alérgicas: hipersensibilidade medicamentosa (HM). Revista Clínica Veterinária, v. 5, n. 1, p. 351-355, 1996.
In cases of possible drug-induced etiology, one could resort to a provocative exposure, a procedure that fully proves the suggested etiological presupposition. However, it is generally contraindicated due to possible ethical problems, particularly to the risk of eliciting tegumentary aggravations or systemic diseases (MILLER et al., 2013; LARSSON, 2016).

LARSSON, C. E. Farmacodermias. In: LARSSON, C. E.; LUCAS, R. Tratado de medicina externa: dermatologia veterinária. São Paulo: Interbook, 2016. p. 675-697.

MASON, K. V. Cutaneous drug eruptions. Veterinary Clinics: Small Animal Practice, v. 20, n. 6, p. 1633-1653, 1990. doi: 10.1016/S0195-5616(90)50165-5.

MILLER, W. H.; GRIFFIN, C. E.; CAMPBELL, K. L.; MULLER, G. H. Muller and Kirk's small animal dermatology. 7. ed. London: Saunders, 2013.

NUTTALL, T.J.;MALHAM, T.Successfulintravenoushuman immunoglobulin treatment of drug-induced Stevens-Johnson syndrome in a dog. Journal of Small Animal Practice, v. 45, n. 7, p. 357-361, 2004. doi: 10.1111/j.1748-5827.2004.tb00248.x.

SAMPAIO, S. A. P.; RIVITTI, E. A. Erupções por drogas. In: SAMPAIO, S. A. P.; RIVITTI, E. A. Dermatologia. São Paulo: Artes Médicas, 2001. p. 603-619.

SCOTT, D. W.; MILLER JUNIOR, W. H. Idiosyncratic cutaneous adverse drug reactions in the dog: literature review and report of 101 cases (1990-1996). Canine Practice, v. 24, n. 5, p. 16-22, 1999.

SOUSA, M. G.; TALIERI, I. C.; JORGE, A. T. B.; COSTA, M. T. Reação farmacodérmica decorrente do uso do levamisol: relato de caso. Arquivo Brasileiro de Medicina Veterinária e Zootecnia, v. 57, p. 154-157, 2005. Supplement 2. doi: 10.1590/S0102-09352005000800004. 